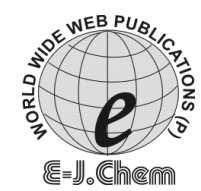

http://www.e-journals.net

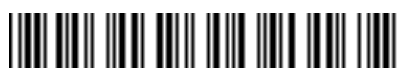

ISSN: 0973-4945; CODEN ECJHAO

E-Journal of Chemistry

Vol. 4, No.3, pp. 434-439, July 2007

\title{
Assessment of Ground Water Quality in and around Gobichettipalayam Town Erode District, Tamilnadu
}

\author{
P. N. PALANISAMY*, A. GEETHA, \\ M. SUJATHA, P. SIVAKUMAR and K. KARUNAKARAN ${ }^{\#}$ \\ Department of Chemistry, Kongu Engineering College, Perundurai-638 052, Tamilnadu. \\ \#Department of Chemistry, Sona College of Technology, Salem - 5, Tamilnadu. India.
}

shivagobi@yahoo.com

Received 5 February 2007; Accepted 4 March 2007

\begin{abstract}
Ground water samples collected from different localities in and around Gobichettipalayam town, Erode District, Tamil Nadu were analyzed for their physico- chemical characteristics. This analysis result was compared with the WHO \& ICMR standards of drinking water quality parameters with the following water quality parameters namely $\mathrm{pH}$, Electrical conductivity, $\mathrm{CN}^{-}, \mathrm{Cl}^{-}, \mathrm{SO}_{4}^{2-}, \mathrm{Na}^{+}, \mathrm{K}^{+}, \mathrm{Ca} \& \mathrm{Mg}$ in $\mathrm{CaCO}_{3}$ equivalents, phenolphthalein alkalinity, hydroxide alkalinity, carbonate alkalinity, bicarbonate alkalinity, total alkalinity, total dissolved solids, total solids, total suspended solids, calcium, magnesium, total hardness, dissolved oxygen, fluoride etc., The usefulness of these parameters in predicting ground water quality characteristics were discussed. Thus an attempt has been made to find the quality of ground water in and around Gobichettipalayam town, suitable for drinking purposes or not.
\end{abstract}

Keywords: Physico- chemical characteristics, Drinking water quality parameters, Ground water.

\section{Introduction}

The quality of ground water depends on various chemical constituents and their concentration, which are mostly derived from the geological data of the particular region. Ground water occurs in weathered portion, along the joints and fractures of the rocks. In fact, industrial waste and the municipal solid waste have emerged as one of the leading cause of pollution of surface and ground water. In many parts of the country available water is 
rendered non-potable because of the presence of heavy metal in excess. The situation gets worsened during the summer season due to water scarcity and rain water discharge. Contamination of water resources available for household and drinking purposes with heavy elements, metal ions and harmful microorganisms is one of the serious major health problems. As a result huge amount of money is spent for chemical treatment of contaminated water to make it potable. Thus there is a need to look for some useful indicators, both chemical and physical, which can be used to monitor both drinking water operation and performance. Gobichettipalayam area comprises different types of Archaean crystalline formations. The main water source for the town is from Bhavani River which is situated Northern side of the town and from LBP (Lower Bhavani Project) which is at southern side of the town. It was estimated that in Gobichettipalayam town, the gross area irrigated from the ground water source was 6222 hectares during the year 2001-2002, 9180 hectares in 2002-2003 and 5471 hectares in 2003-2004. Regarding the annual rainfall details, it was estimated that $616.6 \mathrm{~mm}$ of rainfall during the year 2001-2002, $825.1 \mathrm{~mm}$ in 2002-2003 and $782.2 \mathrm{~mm}$ in 2003-2004.

At present there is no major industry in and around the study area, yet household waste water and garbage (municipal sewage) are directly discharged into the area. The water supply for human consumption is often directly sourced from ground water without biochemical treatment and the level of pollution has become a cause for major concern. The water used for drinking purpose should be free from toxic elements, living and non-living organisms and excessive amount of minerals that may be harmful to health. Keeping this in focus, the quality aspects of ground water in Gobichettipalayam area were analyzed for general water quality, pollution due to industrial discharges and pollution due to municipal sewage. Hence, it is highly essential to examine the presence of toxic substances in distribution water for potable purpose before it is used for drinking. Thus in this paper an attempt has been made to assess the physical and chemical properties of ground water in and around Gobichettipalayam town.

\section{Experimental}

\section{Sampling sites}

For the present study, the area in and around Gobichettipalayam town, Erode District, Tamilnadu was selected. It covers 10 sq.km from the town. The selected areas were categorized into five zones. These were; zone 1 (North of Gobi); zone 2 (South of Gobi); zone 3 (Middle of Gobi); zone 4 (East of Gobi); and zone 5 (West of Gobi).Overall, 20 sampling sites including 5 samples in zone1, 4 samples in zone 2, 4 samples in zone 3, 4 samples in zone 4 and 3 samples in zone 5 were collected for monitoring the physicochemical status of the ground water.

\section{Sample collection}

Water samples from the selected sites were collected during Feb-March 2006 and taken in pre-cleaned polyethylene bottles. The samples after collection were immediately placed in dark boxes and processed within $6 \mathrm{~h}$ of collection.

\section{Physico-chemical analysis}

The collected samples were analyzed for major physical and chemical water quality parameters like $\mathrm{pH}$, Electrical conductivity (EC), Total Dissolved solids (TDS), total hardness (TH), $\mathrm{Ca}^{2+}, \mathrm{Mg}^{2+}, \mathrm{Na}^{+}, \mathrm{K}^{+}, \mathrm{CO}_{3}{ }^{2-}, \mathrm{HCO}_{3}^{-}, \mathrm{OH}^{-}, \mathrm{Cl}^{-}, \mathrm{F}^{-}$and $\mathrm{SO}_{4}{ }^{2-}$ as per the method 
described in "Standard methods for the examination of water and wastewater", American Public Health Association (APHA) ${ }^{2}$.The parameters present in the water sample can be calculated by using various methods $\mathrm{s}^{3-4}$. The $\mathrm{pH}$ of the samples were determined using a $\mathrm{pH}$ electrode 9107 and an expandable ion analyzer EA 940. Electrical conductivity was measured using an Elico CM-180 conductivity meter and sulphate by turbidimetric method using a spectronic-20 (Bosch and Lamb,USA) $)^{5}$.The fluoride ion concentration was measured using Orion ion analyser EA940 with fluoride ion selective electrode (all Orion, USAmake $)^{6}$.The chloride, total hardness and total alkalinity were estimated by the standard methods of water and waste water ${ }^{7}$.

\section{Results and Discussion}

The values of various parameters were furnished in the Table 1 . The results indicates that the quality of water considerably varies from location to location. The underground water is characterized by a relatively constant $\mathrm{pH}$ of around 6.5 to 7.15 for the samples collected from Bhavani River and LBP canal. Water samples with low $\mathrm{pH}$ may be attributed to the discharge of acidic water into this sources by the agricultural and domestic activities. Samples collected form the Sampling points Nadarkurai and Near PKR College were slightly basic which can be seen from its $\mathrm{pH}$ and alkalinity values. Fluoride was also present within the permissible limit. There is no major cause for this alkalinity by any means of human activities. In fact $98 \%$ of all world ground water are dominated by Calcium and bicarbonate ions due to lime stone weathering in the catchments and under ground water beds ${ }^{8}$. The EC values were found higher at sampling points LBP canal and Anuman Kovil Street due to concentrated colloids in canal water and dissolved salts in Nadarkurai. Very low conductivity was found at sampling points Kodishwaran Nagar, Chellapa Nagar \& Kallipatti due to dilution of the contaminants by percolating rainwater. No cyanide was identified even in trace amounts, this may be due to the absence of chemical industries in the near by places of our focus area. The marine component comprises sea salts and the terrestrial supplies are limited to dust and biogenic emissions, while the anthropogenic components in this area are likely limited due to a lack of industry. The values of salts such as $\mathrm{Na}, \mathrm{K}, \mathrm{Ca}, \mathrm{Mg}, \mathrm{Cl}^{-}$and $\mathrm{SO}_{4}{ }^{2-}$ suggested that the surface water sources posses very low marine components, while underground water sources which are far away from surface ground water or Dam water source were found to possess higher amounts of marine components.

The water samples from Kodishwaran Nagar, Chellappa Nagar, Karattadipalayam and near PKR college were found to possess high TDS value when compared with the tolerance limit of $1500 \mathrm{ppm}$. Among this, the water sample from near PKR College having TDS in the order of $2900 \mathrm{ppm}$. The TDS was found to be low for the water samples collected from the Bhavani River and LBP canal. Samples from the sources Pariyur, Mettuvalavu and Gandhi Nagar showed low level of TDS of the range less than $250 \mathrm{ppm}$, which indicates that the recharging of under ground water through either rain water or by the water from near by canals. The possibilities of dissolution of rockey minerals are very low. TDS in all the samples found nil which is a good indicator that there is no direct seepage of contaminated surface water or any sewage water into the water sources. The Dissolved Oxygen of the water samples varies from 4.0 to $8.8 \mathrm{ppm}$ from the points Kodishwaran Nagar, D.G.Pudur and Mettuvlavu. This may be attributed that poor recharge of these sources by surface sources like Rainwater harvesting and canal water. All the water samples invariably had very low level of fluoride contents which is a good sign for the usage of this water for potable purpose. 
Table 1. Water Quality parameters of Samples Collected in and Around Gobichettipalayam Town (Erode District, Tamilnadu)

\begin{tabular}{|c|c|c|c|c|c|c|c|c|c|c|c|c|c|c|c|c|c|c|c|c|c|}
\hline \multirow[t]{2}{*}{$\begin{array}{l}\text { Parameter / } \\
\text { Sample }\end{array}$} & \multirow[t]{2}{*}{ 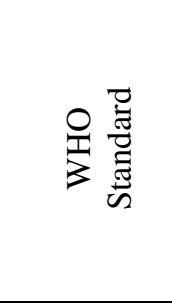 } & 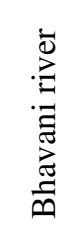 & 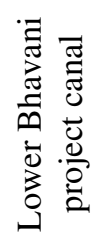 & 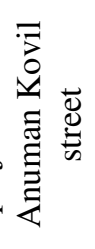 & 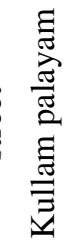 & 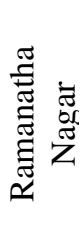 & 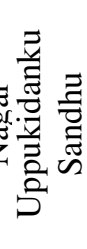 & 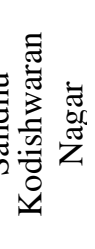 & 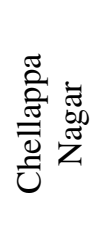 & 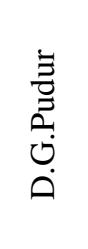 & 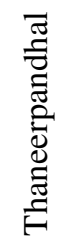 & : & 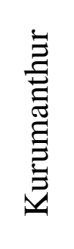 & 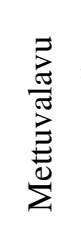 & 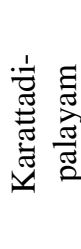 & 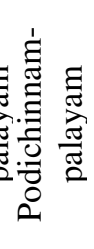 & $\frac{\pi}{\tilde{Z}}$ & 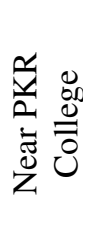 & 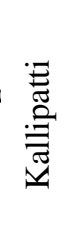 & 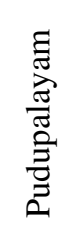 & 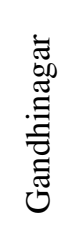 \\
\hline & & 1 & 2 & 3 & 4 & 5 & 6 & 7 & 8 & 9 & 10 & 11 & 12 & 13 & 14 & 15 & 16 & 17 & 18 & 19 & 20 \\
\hline $\mathrm{pH}$ & $7.0-8.5$ & 6.46 & 6.07 & 7.14 & 7.15 & 6.61 & 6.91 & 6.98 & 6.84 & 7.01 & 6.98 & 6.60 & 6.88 & 6.78 & 6.83 & 6.50 & 8.23 & 7.387 & 7.00 & 6.91 & 6.66 \\
\hline $\mathrm{EC}, \mathrm{mV}$ & 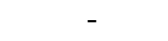 & 3.0 & 55.1 & 9.2 & 8.8 & 22.8 & 5.6 & 0.6 & 9.7 & 0.8 & 1.2 & 23.8 & 7.0 & 12.6 & 10.4 & 29.6 & 72.6 & 23.1 & 0.2 & 5.6 & 20.3 \\
\hline Chloride, ppm & $200-600$ & 35 & 35 & 128 & 35 & 326 & 113 & 517 & 475 & 376 & 85 & 129 & 71 & 546 & 447 & 135 & 92 & 830 & 92 & 176 & 35 \\
\hline Sulphate, ppm & $200-400$ & 0 & 0 & 77 & 0 & 159 & 676 & 280 & 210 & 160 & 127 & 26 & 0 & 228 & 166 & 140 & 14 & 163 & 134 & 104 & 0 \\
\hline Sodium & - & 0 & 0 & 90 & 0 & 130 & 80 & 330 & 275 & 230 & 25 & 25 & 0 & 330 & 105 & 30 & 0 & 550 & 25 & 135 & 0 \\
\hline Potassium, ppm & - & 0 & 0 & 0 & 0 & 0 & 0 & 0 & 0 & 0 & 0 & 28 & 0 & 0 & 10 & 0 & 0 & 0 & 0 & 0 & 0 \\
\hline Calcium, ppm & $75-200$ & 65 & 40 & 180 & 95 & 145 & 180 & 425 & 385 & 250 & 265 & 225 & 190 & 300 & 625 & 175 & 185 & 250 & 260 & 175 & 25 \\
\hline Magnesium, ppm & $30-150$ & 50 & 35 & 240 & 205 & 325 & 170 & 440 & 495 & 470 & 300 & 135 & 160 & 275 & 485 & 390 & 70 & 550 & 250 & 310 & 95 \\
\hline $\begin{array}{l}\mathrm{OH}^{-} \text {Alkalinity, } \\
\text { ppm }\end{array}$ & - & 0 & 0 & 0 & 0 & 0 & 0 & 0 & 0 & 0 & 0 & 0 & 0 & 0 & 0 & 0 & 0 & 160 & 0 & 0 & 0 \\
\hline $\begin{array}{l}\text { Carbonate } \\
\text { Alkalinity, ppm }\end{array}$ & - & 0 & 0 & 0 & 0 & 0 & 0 & 0 & 0 & 0 & 0 & 0 & 0 & 0 & 0 & 0 & 1720 & 640 & 0 & 0 & 0 \\
\hline $\begin{array}{l}\text { Bicarbonate } \\
\text { Alkalinity, ppm }\end{array}$ & - & 94 & 48 & 69 & 98 & 37 & 52 & 63 & 58 & 54 & 40 & 193 & 97 & 50 & 14 & 68 & 510 & 0 & 0 & 0 & 0 \\
\hline $\begin{array}{l}\text { Total Alkalinity, } \\
\text { ppm }\end{array}$ & - & 94 & 48 & 69 & 98 & 37 & 52 & 63 & 58 & 54 & 40 & 193 & 97 & 50 & 14 & 68 & 1930 & 800 & 0 & 0 & 0 \\
\hline $\begin{array}{l}\text { Total Dissolved } \\
\text { Solids, ppm }\end{array}$ & $500-1500$ & 160 & 20 & 840 & 300 & 1100 & 900 & 1960 & 1980 & 600 & 860 & 240 & 540 & 244 & 2400 & 0900 & 360 & 2900 & 650 & 1120 & 200 \\
\hline $\begin{array}{l}\text { Total Hardness, } \\
\text { ppm }\end{array}$ & $200-600$ & 115 & 75 & 420 & 300 & 770 & 350 & 865 & 880 & 720 & 565 & 360 & 350 & 875 & 1110 & 565 & 255 & 800 & 515 & 485 & 120 \\
\hline $\begin{array}{l}\text { Dissolved Oxygen } \\
\text { ppm }\end{array}$ & $5.0-6.0$ & 8.20 & 5.00 & 5.60 & 6.60 & 5.20 & 6.00 & 4.80 & 6.20 & 4.80 & 6.60 & 5.00 & 6.00 & 4.00 & 8.80 & 8.00 & 7.40 & 7.007 & 7.60 & 5.80 & 5.60 \\
\hline Fluoride, ppm & $1.0-1.5$ & 0.71 & 0.69 & 0.73 & 0.81 & 0.83 & 0.61 & 0.65 & 0.59 & 0.63 & 0.83 & 0.86 & 0.37 & 0.46 & 0.00 & 0.00 & 0.71 & 0.21( & 0.36 & 0.41 & 0.00 \\
\hline
\end{tabular}




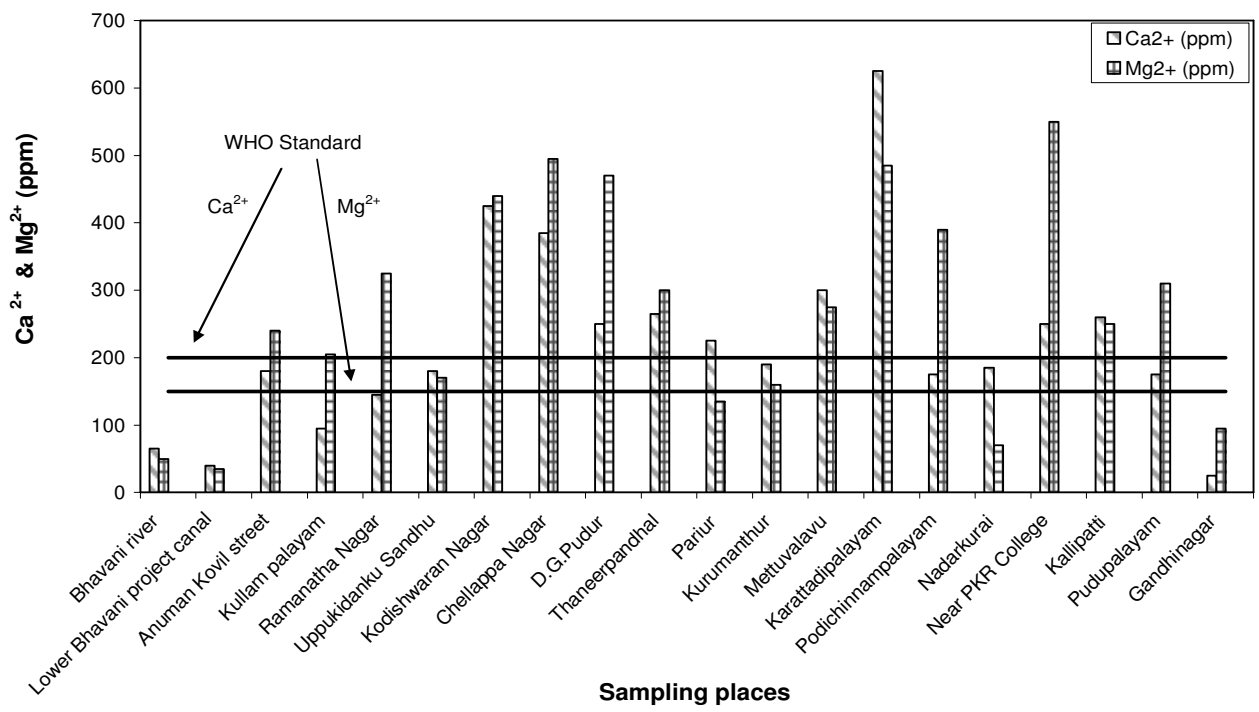

Figure $1 . \mathrm{Ca}^{2+}$ and $\mathrm{Mg}^{2+}$ (ppm) values of vairous water samples collected in and around Gopichettipalaym town

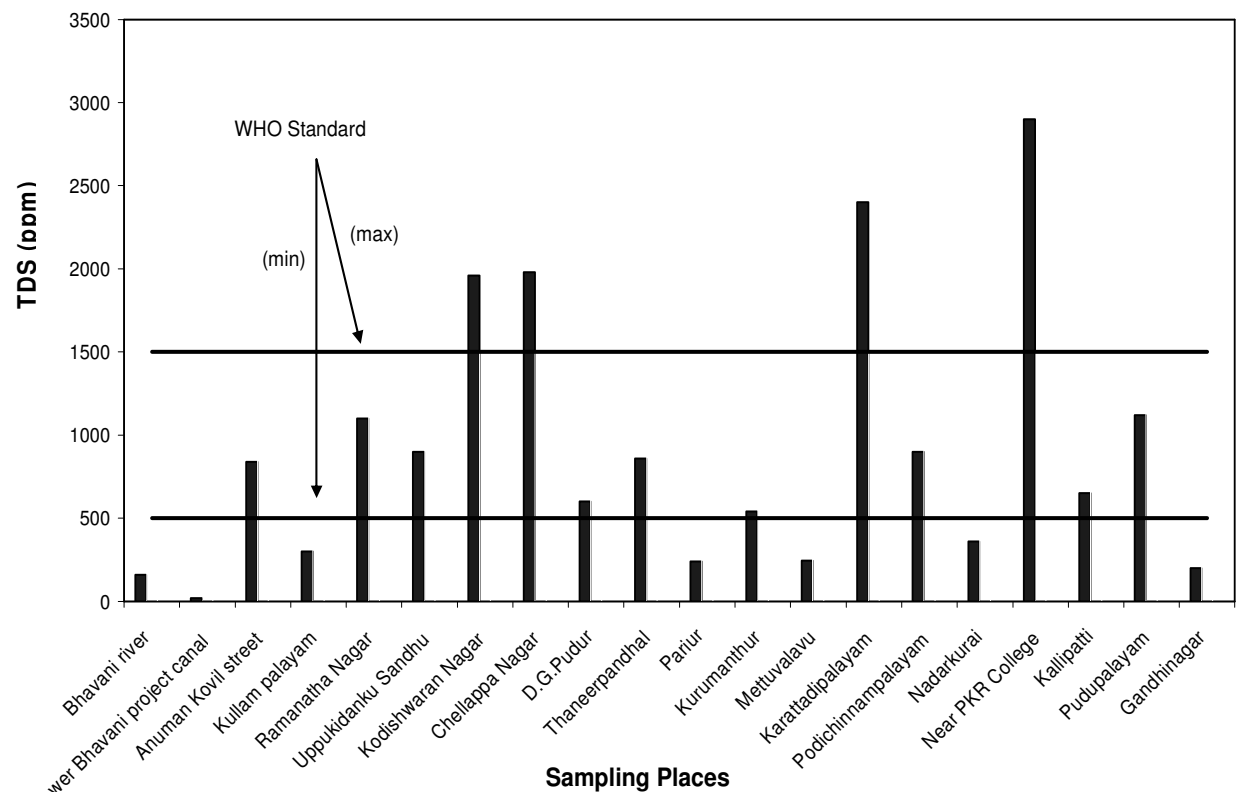

Figure 2. Total dissolved solids (ppm) of various water samples collected in and around Gopichettipalayam. 


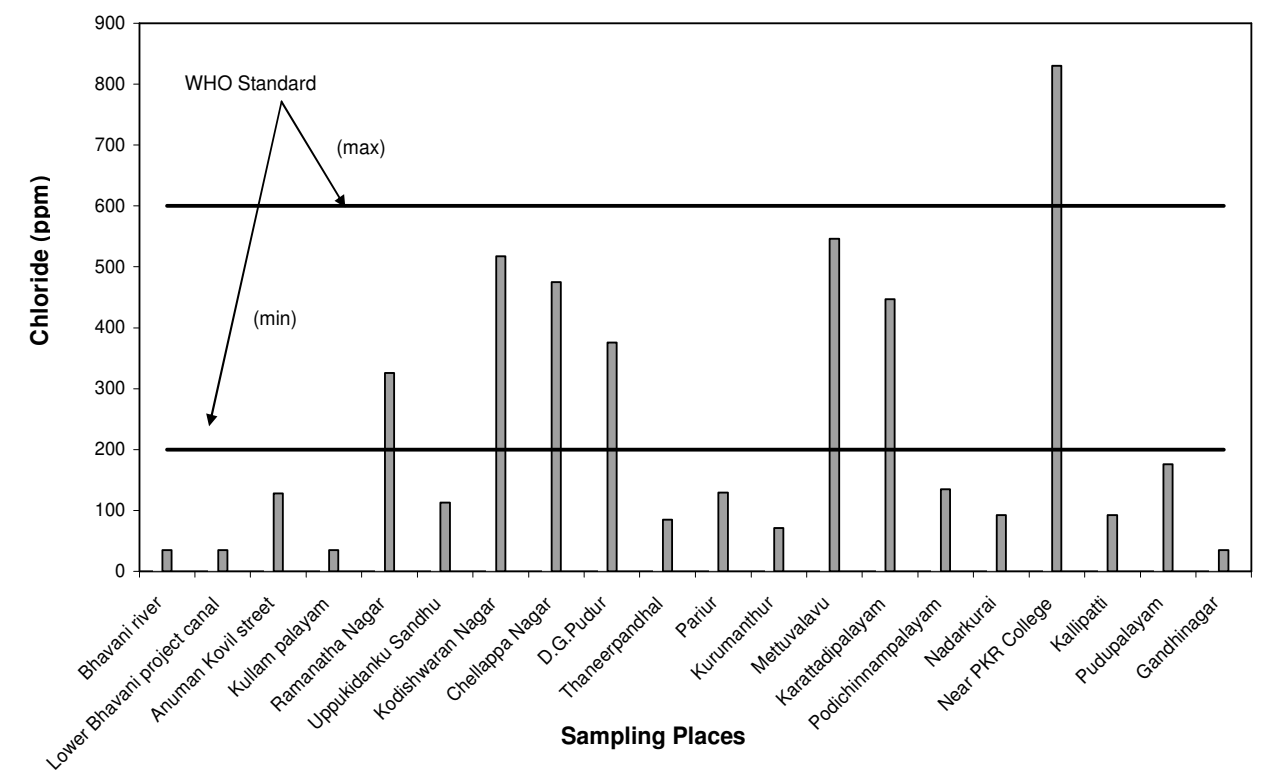

Figure 3. Chloride content(ppm) of various water samples collected in and around Gopichettipalayam town.

\section{Conclusions}

The ground water which were taken from the various places of in and around Gobichettipalayam town were analyzed and the analysis reports that the water quality parameters like $\mathrm{pH}, \mathrm{EC}, \mathrm{Cl}^{-}, \mathrm{SO}_{4}{ }^{2-}$, TDS $, \mathrm{Ca}^{2+}, \mathrm{Mg}^{2+}$, Hardness and fluoride lies within the maximum permissible limit prescribed by WHO and ICMR. Except few parameters like DO, few samples were reported with lower DO than the permissible level, but this value does not have any impact for the water to use for drinking purpose. According to this report, the ground water in and around Gobichettipalayam is suitable for drinking purposes, agricultural utilization, industrial purposes and generally it is not harmful to human beings.

\section{References}

1. Groundwater perspectives - A profile of Erode District, Tamilnadu State Ground and Surface Water Resources Data Centre, Water Resources Organisation, Public Work Department, Government of Tamilnadu, Chennai, India,2000.

2. APHA, Standard methods for analysis of water and wastewater. $18^{\text {th }}$ Ed. American Public Health Association, Inc., Washington DC. 1992.

3. Manivasakam N, Physical Chemical examination of water, sewage and industrial effluents $3^{\text {rd }}$ Ed, Pragati Prakashan, Meeret, India, 1996.

4. Nagarajan S, Swaminathan M and Sabarathinam P L, Poll. Res., 1993, 12(4), 245 - 250.

5. Hart V S, Johnson C E and LeHerman R D, J.Amer.Water Assoc., 1992, 84, 40.

6. $\quad$ Fluoride Electrode Instruction Manual, Orion.Res.Inc., USA., 1997.

7. Standard Methods for the examination of water and wastewater, APHA $16^{\text {th }}$ Ed., Washington DC, 1985.

8. Meybeck M, Rev. Geol. Dyn. Geogr. Phys., 1979, 21, 215-246. 


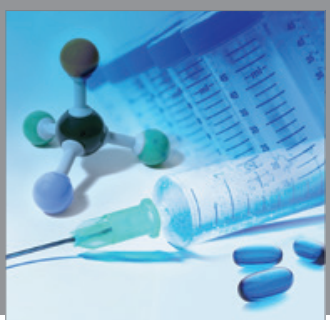

International Journal of

Medicinal Chemistry

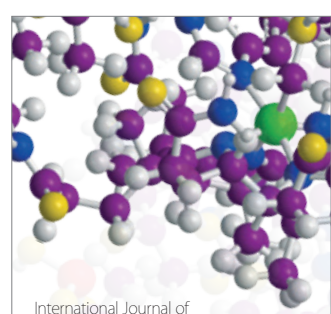

Carbohydrate Chemistry

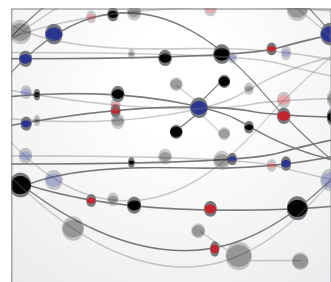

The Scientific World Journal
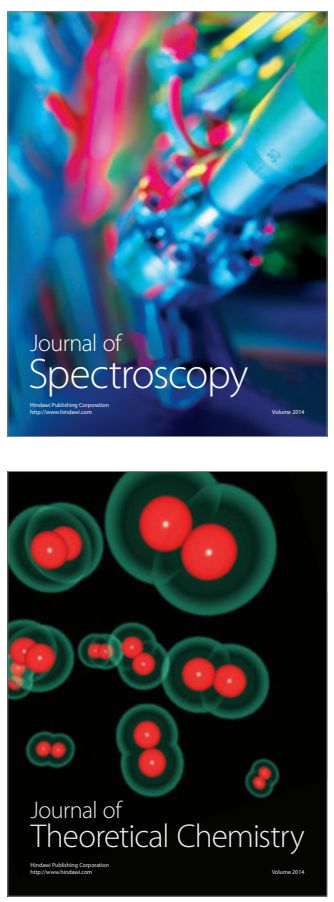
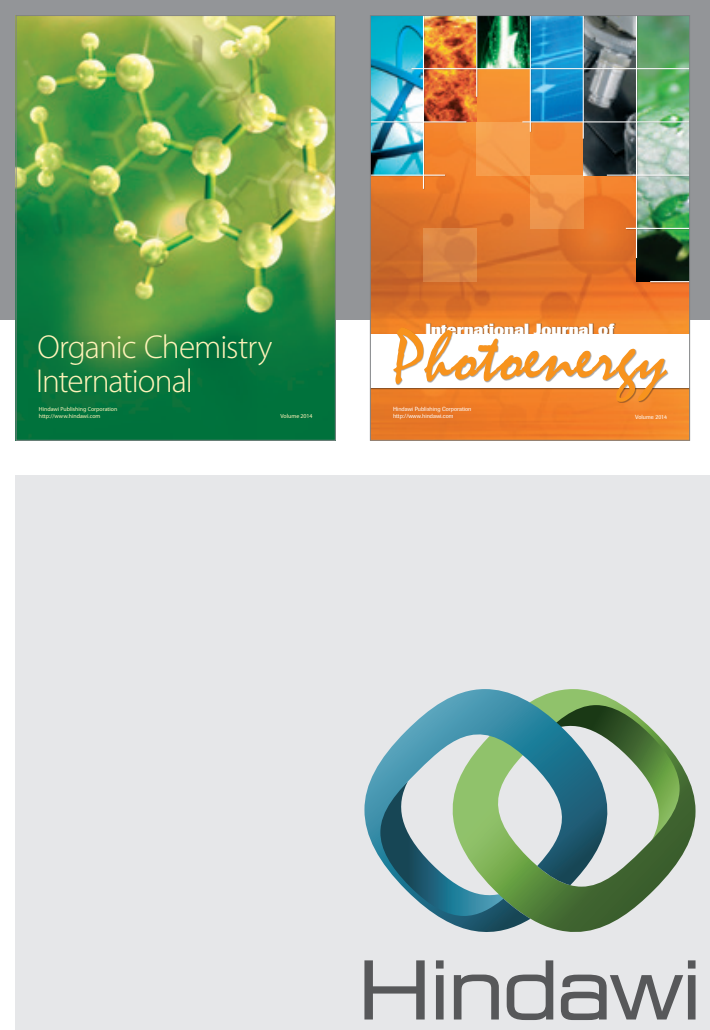

Submit your manuscripts at

http://www.hindawi.com
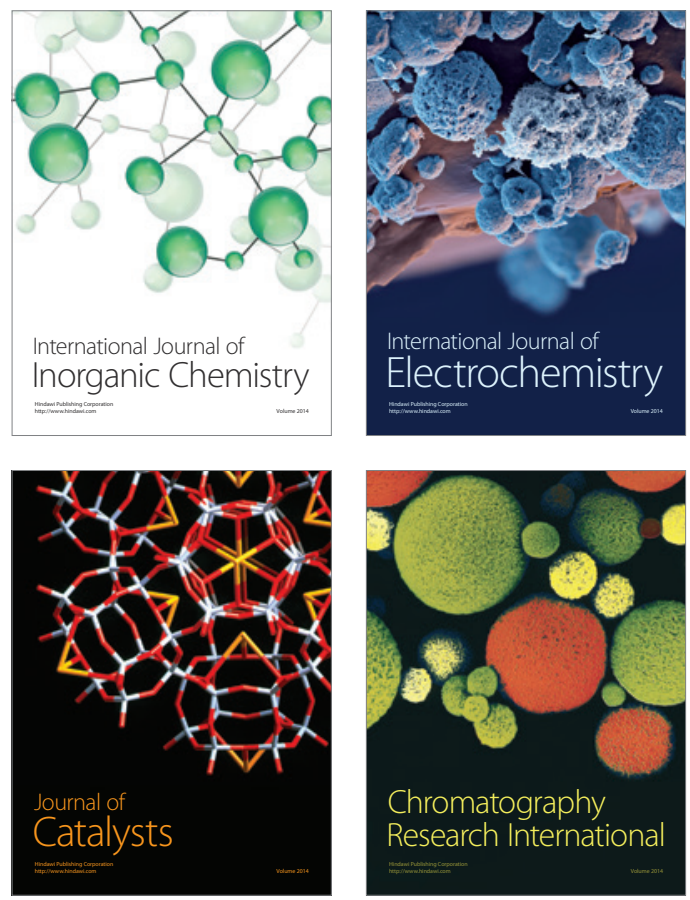
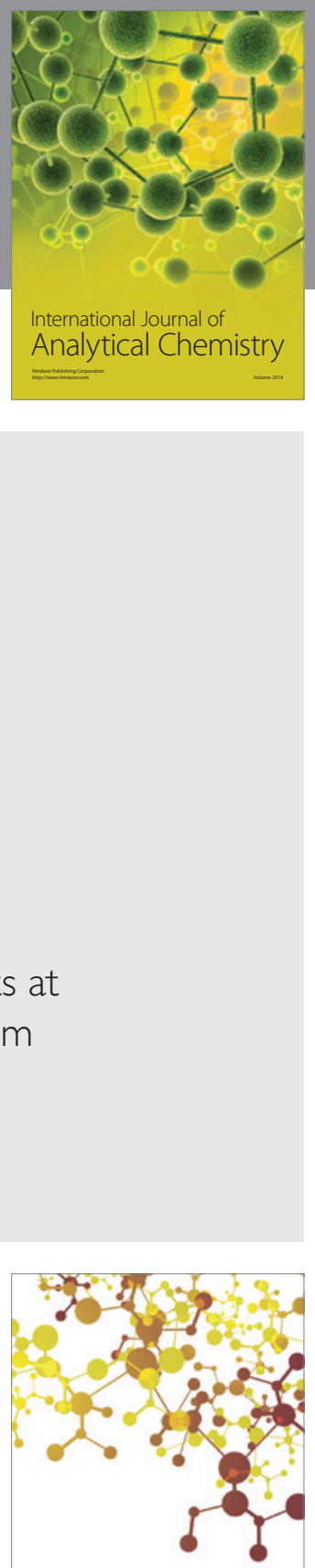

Journal of

Applied Chemistry
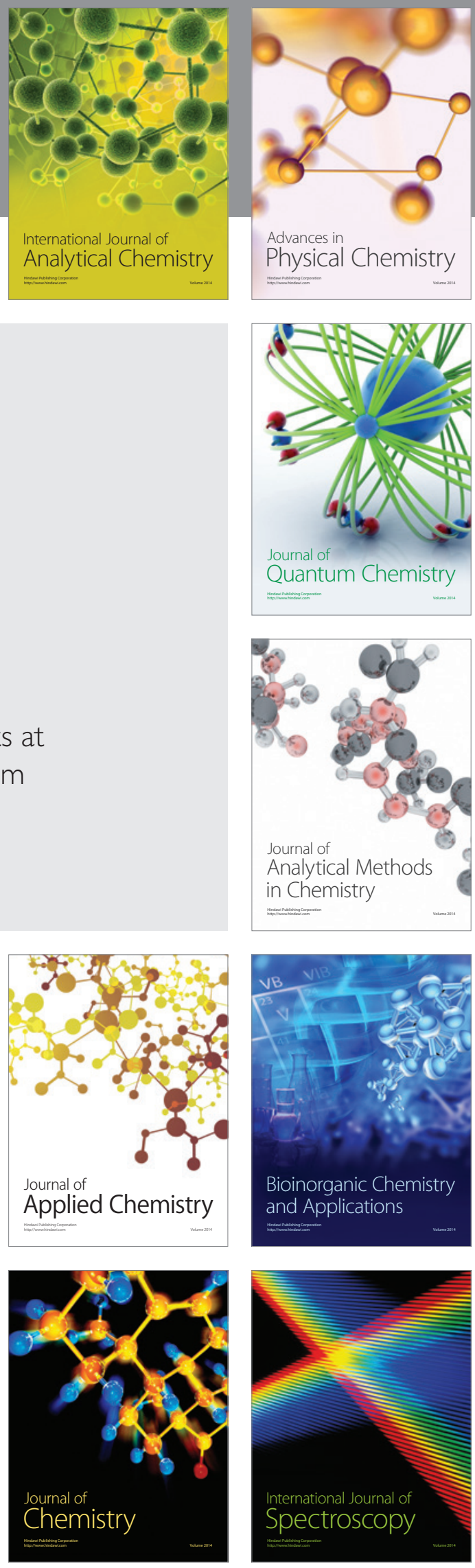